\title{
A rapid access to the core skeleton of atypical tricyclic polyprenylated acylphloroglucinols
}

\author{
Blanca Tolon, ${ }^{\text {a,b }}$ Bernard Delpech, ${ }^{\text {b,* }}$ and Christian Marazano ${ }^{\mathrm{b}, \dagger}$ \\ ${ }^{a}$ Center of Pharmaceutical Chemistry, Calle 200, esq. 21, Atabey, 16042, Havana City, Cuba \\ ${ }^{b}$ Centre de Recherche de Gif, Institut de Chimie des Substances Naturelles CNRS, \\ Avenue de la Terrasse, 91198 Gif-sur-Yvette Cedex, France \\ E-mail: bernard.delpech@icsn.cnrs-gif.fr
}

\section{Dedicated to the memory of Christian Marazano \\ ${ }^{\dagger}$ Deceased on November $12^{\text {th }} 2008$}

\begin{abstract}
A synthesis of $\left(4 S^{*}, 6 S^{*}\right)-2,4,6$-triallyl-3,3-dimethylcyclohexanones, and the treatment of their TMS enol ethers with malonyl dichloride in the presence of $\mathrm{BF}_{3} \cdot \mathrm{Et}_{2} \mathrm{O}$, are reported. Formation of a ketoacid, resulting from acylation without cyclization, and of a tricyclic phloroglucinol derivative, involving Effenberger annulation with concomitant $O$-cyclization, were obtained. The tricyclic compound has the core skeleton of the hyperibones $\mathrm{H}$ and I, atypical natural polycyclic polyprenylated acylphloroglucinols. Mechanistic and stereochemical aspects are discussed.
\end{abstract}

Keywords: Polycyclic polyprenylated acylphloroglucinols (PPAPs), silyl enol ethers acylation, Effenberger annulation, malonyl dichloride, bicyclo[3.3.1]nonane-2,4,9-triones

\section{Introduction}

More than one hundred polycyclic polyprenylated acylphloroglucinols (PPAPs) with a bicyclo[3.3.1]nonane-2,4,9-trione core skeleton have been isolated from plants and trees of the family Clusiaceae (Guttiferae), some of them presenting interesting biological activities. ${ }^{1}$ These compounds can be divided principally into two classes, with type A possessing a bridgehead acyl group adjacent to a quaternary center, and type B having two bridgehead isoprenyl chains and an acyl group bound to C-3. ${ }^{2}$ Moreover, irrespective of the type (A or B), some PPAPs have the 7substituent either in an equatorial exo position (i.e., nemorosone, ${ }^{2}$ clusianone, ${ }^{3}$ or aristophenone ${ }^{4}$ ) or in an axial endo position (i.e., 7-epi-nemorosone ${ }^{5}$ or xanthochymol $^{6}$ ). Finally, natural products with a tricyclic core, with an oxygen heterocycle, are also found as in the case of garsubellin $\mathrm{A}^{7}$ or of hyperibone $\mathrm{I}^{8}$ with their 4-oxa-tricyclo[6.3.1.0 $\left.0^{1,5}\right]$ dodec-5-ene-7,12-dione skeletons. 


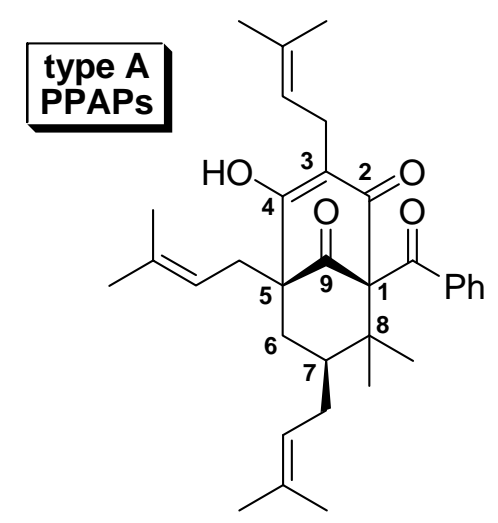

nemorosone

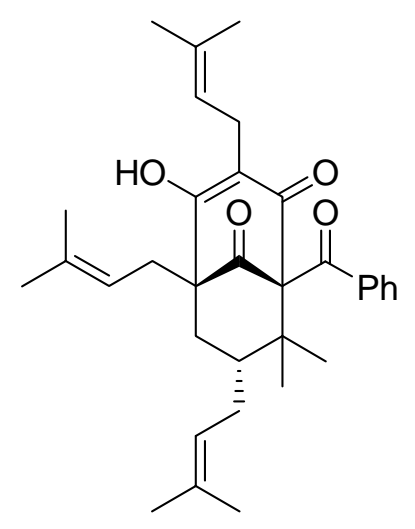

7-epi-nemorosone
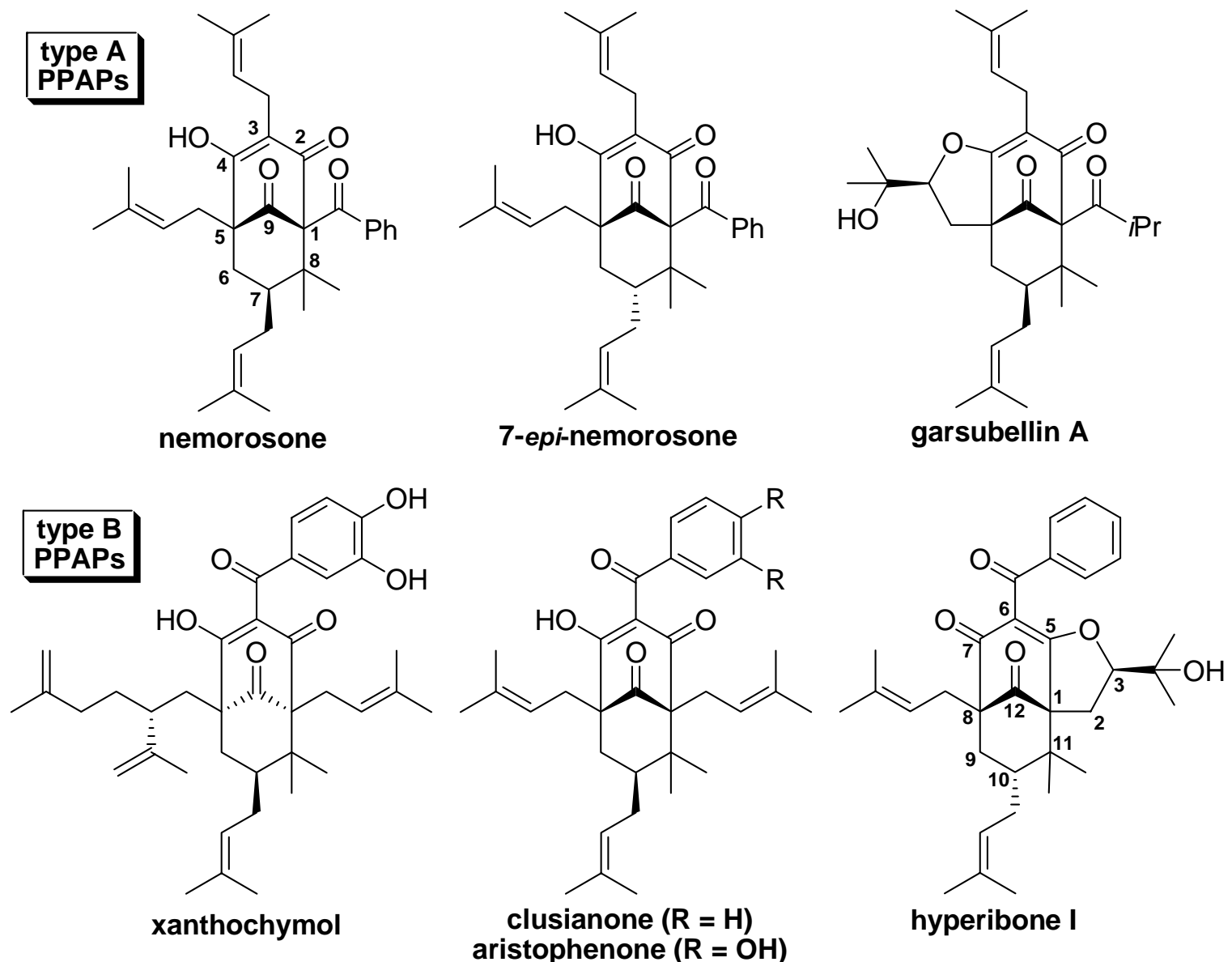

The first total syntheses of a PPAP were those of garsubellin A (type A). ${ }^{9}$ Syntheses of clusianone (type B) were subsequently reported by several groups ${ }^{10}$ including ours. ${ }^{11}$ Nemorosone also has been the subject of a total synthesis. ${ }^{10 \mathrm{e}}$ Our interest in the field of PPAPs came from the observation that xanthochymol was active in a tubulin disassembly inhibition test. $^{6}$ After our work leading to the isolation of oblongifolins $\mathrm{A}-\mathrm{D},{ }^{12}$ we undertook synthetic studies toward type B PPAPs. ${ }^{11,13}$

We previously showed that the boron trifluoride catalyzed Effenberger $\alpha, \alpha^{\prime}$-annulation ${ }^{14}$ of isomeric 2,4,6-triprenyl-3,3-dimethylcyclohexanones TMS enol ethers $\mathbf{1}$ with malonyl dichloride allowed the formation of the bicyclo[3.3.1]nonane-2,4,9-trione 2 with an equatorial prenyl group. ${ }^{11}$ This led to a short synthesis of $( \pm)$-clusianone via $C$-benzoylation of the enolic $\beta$ dicarbonyl moiety of 2 (Scheme 1). We also observed the formation of interesting secondary products possessing an additional tetrahydropyran ring, owing to the cyclization of a prenyl group with the oxygen of an enol moiety. ${ }^{11}$ 


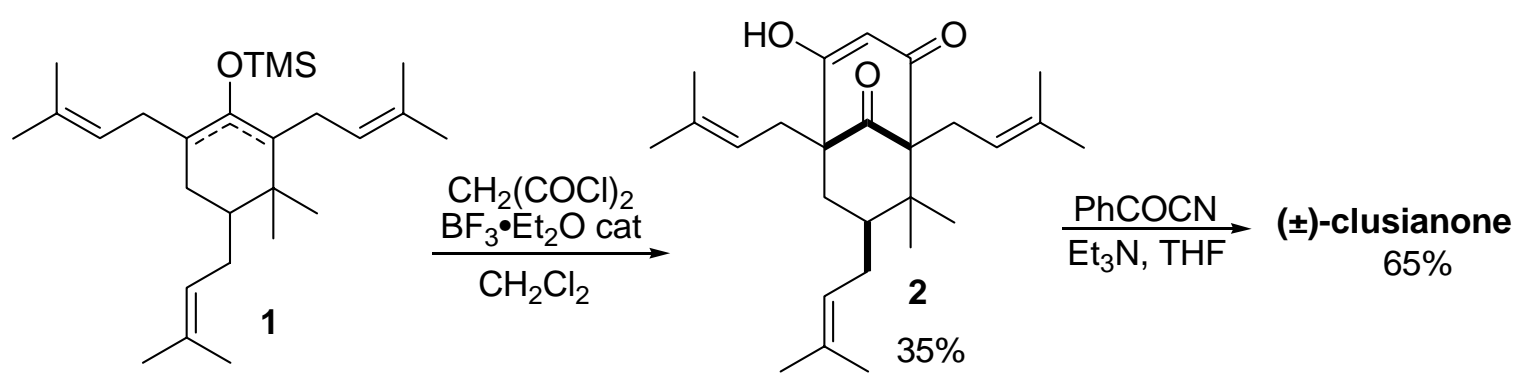

Scheme 1. Synthesis of $( \pm)$-clusianone via Effenberger annulation.

Following up on this observation, we wanted to examine the Effenberger annulation reaction with a compound such as $\mathbf{1}$, but with allyl groups instead of the prenyl chains, in order to minimize undesired cyclizations. Accordingly, we report here our work concerning the preparation of $\left(4 S^{*}, 6 S^{*}\right)-2,4,6$-triallyl-3,3-dimethylcyclohexanones and the reaction of their TMS enol ethers in $\mathrm{BF}_{3} \cdot \mathrm{Et}_{2} \mathrm{O}$ catalyzed Effenberger annulation conditions.

\section{Results and Discussion}

\section{Preparation of $\left(4 S^{*}, 6 S^{*}\right)-2,4,6$-triallyl-3,3-dimethylcyclohexanones 8}

The synthesis of the epimeric pentasubstituted ketones 8 was achieved, according to Scheme 2, the two first steps requiring no purification.<smiles>C=CCC1=C(O)CCCC1=O</smiles>

3<smiles>C=CCC1=C(C)C(CC=C)CCC1=O</smiles><smiles>C=CCC1=C(OCC)CCCC1=O</smiles>

4
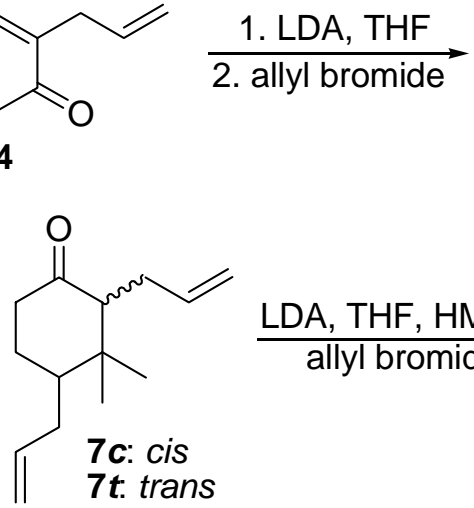

83\% (cis/trans: 4/3)

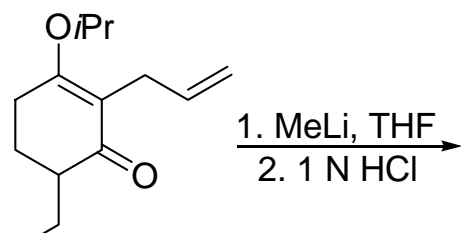

5

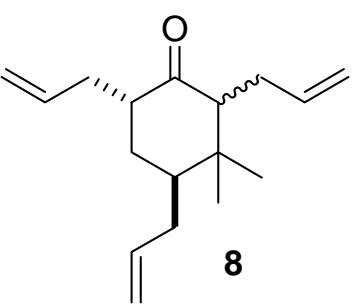

$78 \%(\beta / \alpha: 3 / 2)$

Scheme 2. Synthesis of 2,4,6-triallyl-3,3-dimethylcyclohexanones 8.

Starting from the known 2-allylcyclohexane-1,3-dione $3,{ }^{15} \mathrm{O}$-alkylation with isopropyl iodide ${ }^{16}$ led to the vinylogous ester $\mathbf{4}$. Stork-Danheiser kinetic allylation ${ }^{17}$ of $\mathbf{4}$ followed by methyllithium addition and acidic hydrolysis afforded enone 6 with $87 \%$ yield. $\mathrm{BF}_{3} \cdot \mathrm{Et}_{2} \mathrm{O}$ 
promoted conjugate addition of methylcopper ${ }^{18}$ allowed the formation of the gem-dimethyl ketones 7 as a mixture of cis and trans isomers. The suitably substituted cyclohexanones 8 were obtained, by regio- and stereoselective allylation in the presence of HMPA (axial attack on the less substituted enolate distal from the gem-dimethyl).

\section{Formation of TMS enol ethers 9 and their reaction with malonyl chloride}

Silyl enol ethers $\mathbf{9}$ were formed, with TMSOTf in the presence of triethylamine, and obtained as a mixture of three regio- and stereoisomers, the major products having probably the enolic double bond remote from the gem-dimethyl. ${ }^{19}$ This mixture was used without purification for the annulation step (Scheme 3). We first tested 9 under best conditions we developed for the formation of the bicyclo[3.3.1]nonane-2,4,9-trione $\mathbf{2}$ (one equivalent of malonyl dichloride in the presence of 0.3 equivalent of $\mathrm{BF}_{3} \cdot \mathrm{Et}_{2} \mathrm{O}$, from $-10{ }^{\circ} \mathrm{C}$ to rt). ${ }^{11}$ Final treatment with DMAP, which was used initially in the TMSOTf catalyzed reaction in order to facilitate silyl enol ether reformation and acylation, and also to trap acidic species, was kept with this boron trifluoride variant. $^{11}$

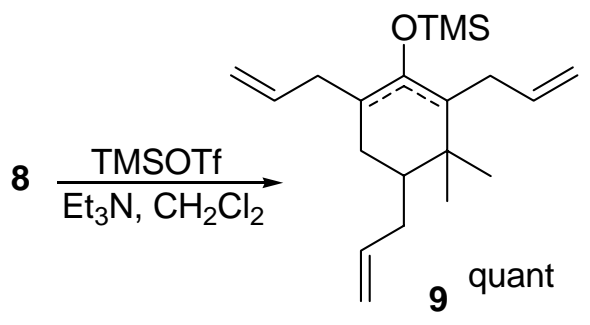

1. $\mathrm{CH}_{2}(\mathrm{COCl})_{2}$ (2 equiv) $\mathrm{BF}_{3} \cdot \mathrm{Et}_{2} \mathrm{O}(0.3$ equiv) $\mathrm{CH}_{2} \mathrm{Cl}_{2},-10^{\circ} \mathrm{C}$ to rt

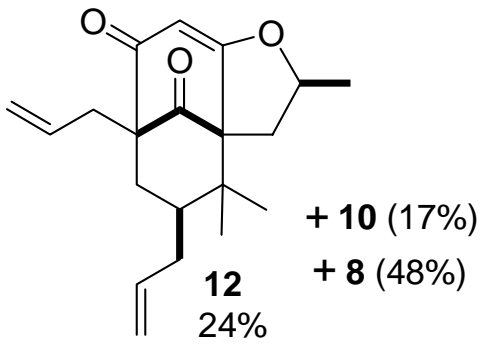

1. $\mathrm{CH}_{2}(\mathrm{COCl})_{2}$ (1 equiv) $\mathrm{BF}_{3} \cdot \mathrm{Et}_{2} \mathrm{O}$ (0.3 equiv) $\mathrm{CH}_{2} \mathrm{Cl}_{2},-10^{\circ} \mathrm{C}$ to rt

2. DMAP (3.5 equiv)

2. DMAP (2.8 equiv)

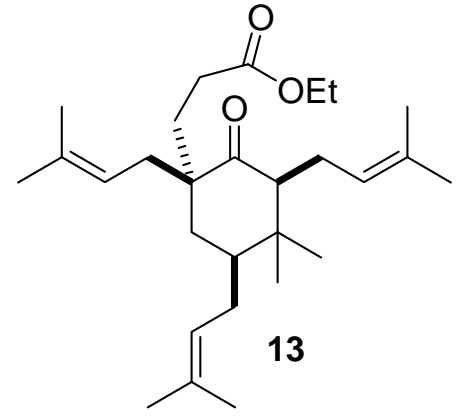

Scheme 3. Reaction of TMS enol ethers $\mathbf{9}$ with malonyl dichloride in the presence of $\mathrm{BF}_{3} \bullet \mathrm{Et}_{2} \mathrm{O}$.

We were surprised to observe no annulation but just a simple acylation, since ketoacid $\mathbf{1 0}$ was isolated after work up, essentially as one isomer, with $27 \%$ yield (67\% corrected yield, based on $60 \%$ of recovered ketones). In order to facilitate purification and analysis of compound 10, it was transformed into $\beta$-ketoester 11 in $87 \%$ yield by treatment with TMSdiazomethane in acetone. The stereochemistry of compound $\mathbf{1 1}$ (three equatorial allyl groups) was deduced by 
NMR spectroscopy, and particularly by comparing the high field chemical shifts, (for ${ }^{1} \mathrm{H}$ as well as for ${ }^{13} \mathrm{C} \mathrm{NMR}$ ), of the axial methyl group with those recorded for the previously obtained triprenyl analogue $13^{13 \mathrm{a}}$ ( $\delta_{\mathrm{H}} 0.57$ for $\mathbf{1 1}$ and 0.56 for $\mathbf{1 3}$ and $\delta_{\mathrm{C}} 15.4$ for $\mathbf{1 1}$ and 15.1 for 13). The values for $\delta_{\mathrm{C}}$ are attributed to the $\gamma$-gauche effect (one equatorial substituent on each side of the gem-dimethyl). ${ }^{20}$

With two equivalents of malonyl dichloride, stoichiometry described by Stoltz in the case of the reaction with a TBS enol ether, ${ }^{19}$ and a longer reaction time at room temperature, Effenberger annulation $^{14}$ could be achieved, but with concomitant $O$-cyclization. These conditions afforded 10 again (17\%) but compound 12 also was isolated as one isomer, with 24\% yield (46\% corrected yield, based on $48 \%$ of recovered ketones). Thus, in a single operation, the tricyclic skeleton of hyperibones $\mathrm{H}$ and I was obtained. It should be noted that these natural products, with a 2-hydroxy-2-propyl substituent at C-3 are, to the best of our knowledge, the only PPAPs with the heterocycle adjacent to the gem-dimethyl group. ${ }^{8}$

For the tricyclic compound 12, the furan ring was positioned adjacent to the gem-dimethyl group, according to correlations of these $\mathrm{CH}_{3}$ groups with the bridgehead $\mathrm{C}-1$ and of $\mathrm{H}-2$ with $\mathrm{C}$ 1 and with the quaternary C-11 observed in the HMBC NMR spectrum (for numbering, see hyperibone I). The carbonyl bridge and the substituent at C-10 were shown to be cis, i.e. with the C-10 allyl group equatorial (exo). This was deduced, as for PPAPs in general, ${ }^{1}$ from the upfield shift of the axial methyl group at C-11 in the ${ }^{13} \mathrm{C}$ NMR spectrum $\left(\delta_{\mathrm{C}} 16.0\right)$, due to the $\gamma$-gauche interaction shielding of this methyl group by the $\mathrm{C}-10$ allyl group. ${ }^{20}$ The value of the chemical shift of C-10 ( $\left.\delta_{\mathrm{C}} 39.7\right)$ is also in agreement with an equatorial substituent bound to this carbon. ${ }^{3 \mathrm{~b}}$ The cis relationship of the methyl group at $\mathrm{C}-3$ (on the heterocycle) with the carbonyl bridge was assumed by comparing coupling constants for $\mathrm{H}-2 \alpha$ and $\mathrm{H}-2 \beta$ with those of hyperibones $\mathrm{H}$ and $\mathrm{I}^{8}$

Formation of the tetrahydrofuran ring is surprising since the allyl group is much less electron-rich than the prenyl group in the initial series. Moreover, cyclization involving the enolic part of the $\beta$-dicarbonyl moiety and the bridgehead substituent adjacent to the gemdimethyl system was unexpected. Such a regioselectivity concerning reactivity of this particular $\beta$-diketonic system is not generally observed for inter- or for intramolecular acidic $O$ alkylations. ${ }^{6,10 \mathrm{a}-c, 19}$ In the case of natural $O$-cyclized type B PPAPs, the heterocycle (usually sixmembered) is also generally distal from the gem-dimethyl group. ${ }^{1,}{ }^{21}$ However, a compound with a tetrahydropyran adjacent to the quaternary carbon has been obtained as a minor product by radical oxidation of garcinol. ${ }^{22}$

A possible mechanistic pathway, which could explain the formation, as well as the stereochemistry, of $\mathbf{1 0}$ and 12, is shown in Scheme 4. Malonyl dichloride, activated by $\mathrm{BF}_{3}$, might acylate the likely major enol ethers $\mathbf{9}$, anti to the 4-allyl group (cyclohexanone numbering) to form $\mathbf{i}$ (attack on the supposed minor isomer is defavored for steric reasons). More generally, alkylation of cyclohexanones enolates possessing a structure analogous to $\mathbf{9}$ proceeds mostly anti to the 4-substituent. ${ }^{9 a, 13 a, 23}$ As the cyclization is difficult (formation of a compound with two contiguous quaternary carbons), slight conformational modifications might prevent the 
chlorocarbonyl function of ii from reaching the optimal distance (and with a favorable geometry) from C-2. Formation of the ketoacid 10, with the stereochemistry shown in Scheme 3, after hydrolytic work up, could reflect the difficulty of cyclization from ii.
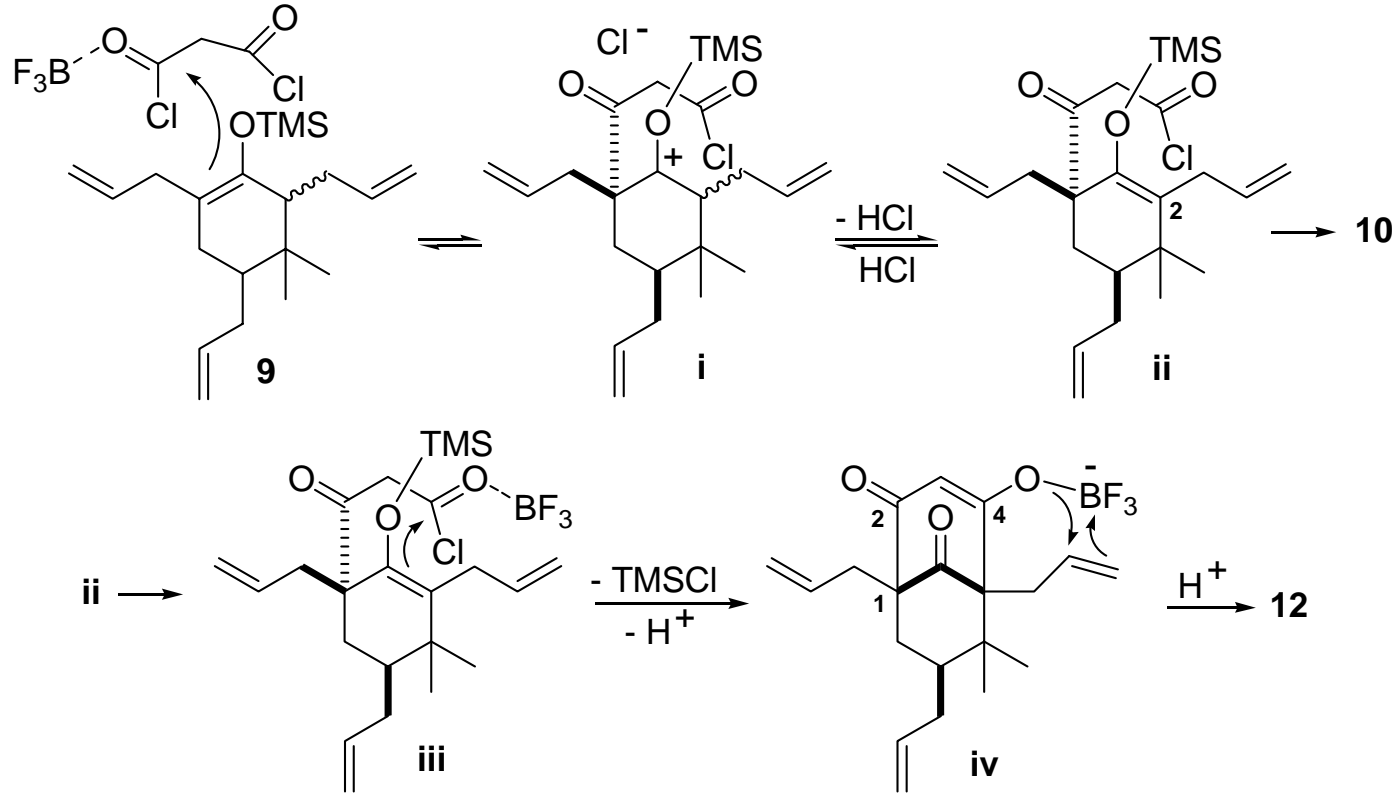

Scheme 4. Tentative mechanistic interpretation.

In the presence of an excess of malonyl dichloride (two equivalents), the rate of formation and the concentration of $\mathbf{i}$ might be increased, as its generation is probably reversible. Therefore, the amount of ii could also be higher, allowing a second acylation, intramolecular this time and possibly via iii, as in the prenyl series. ${ }^{11}$ In the case of the tricyclic product 12, formation of an intermediate (iv) with $\mathrm{BF}_{3}$ coordinated to the oxygen bound to C-4 (bicyclo[3.3.1]nonane-2,4,9trione numbering) might favor the participation of the allyl group close to this oxygen. The ring size is the result of an addition following Markovnikov's rule and the advantage of the allyl group, here, is to afford a five membered heterocycle. 

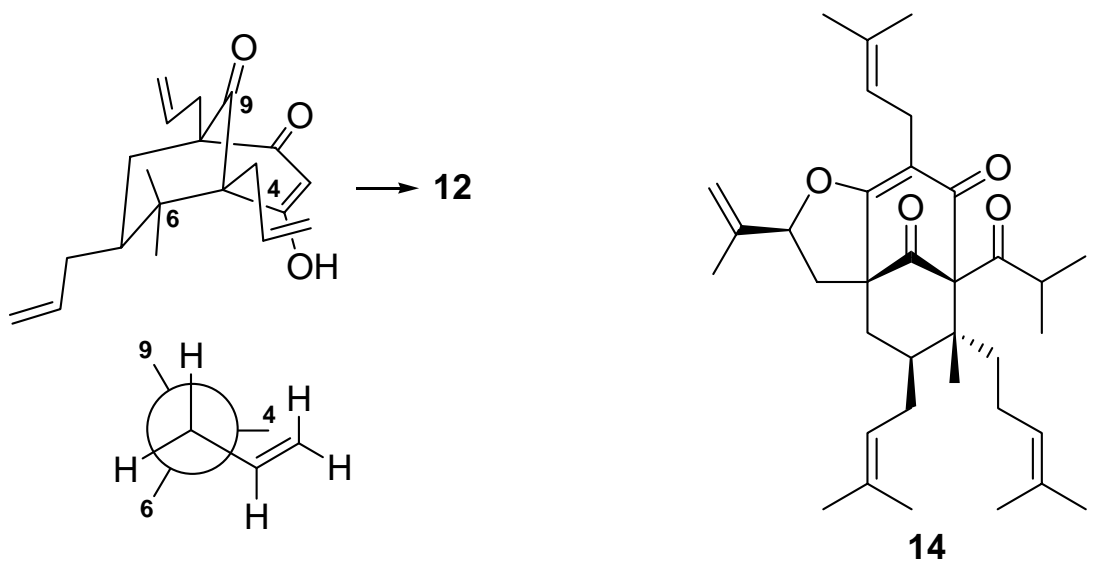

The stereochemistry of $\mathbf{1 2}$ at C-3 could be attributed to a geometry, for the allyl group, close to that of its favored conformation, ${ }^{24}$ as shown above. It should be noted that the formation of $\mathbf{1 4}$, a product of hyperforine lead tetraacetate oxidation, proceeded with a similar stereochemical outcome (cis isopropenyl group and carbonyl bridge). ${ }^{25}$

The less efficient $\alpha, \alpha^{\prime}$-annulation in the case of $\mathbf{9}$, compared to $\mathbf{1}$, and the formation of a tricyclic product only in the case of the allyl substituted derivative remain unclear. However, small differences between allyl and prenyl groups, from steric and conformational points of view, could modify the regioselectivity of TMS enol ethers formation and also affect cyclization processes.

\section{Conclusions}

Reaction of 2,4,6-triallyl-3,3-dimethylcyclohexanones TMS enol ethers 9 with malonyl dichloride in the presence of $\mathrm{BF}_{3} \cdot \mathrm{Et}_{2} \mathrm{O}$, was carried out in order to obtain an allyl substituted bicyclo[3.3.1]nonane-2,4,9-trione. Depending on the conditions, formation of the ketoacid 10, by acylation without cyclization, or of the tricyclic compound 12, by Effenberger $\alpha, \alpha$ '-annulation with concomitant $O$-cyclization, were observed. Thus, in a simple operation, a product with the same core skeleton than that of hyperibones $\mathrm{H}$ and I was obtained.

\section{Experimental Section}

General. NMR spectra were recorded with the following Bruker spectrometers: AC250 (250 $\mathrm{MHz}$ ), AC300 (300 MHz), Avance 300 (300 MHz), DPX 400 (400 MHz) and Avance 500 (500 $\mathrm{MHz}$ ). FTIR spectra were recorded as a film on $\mathrm{NaCl}$ or diamond (SensIR DurasampIRII) cell with a Perkin-Elmer Spectrum BX FT-IR spectrophotometer. Mass spectra were recorded by electrospray ionization with a Micromass LCT (ESI-TOF) spectrometer. 
2-Allyl-3-isopropoxycyclohex-2-enone 4 . To a solution of $3^{15}$ (8.58 g, $56.4 \mathrm{mmol}$ ) in acetone $(112 \mathrm{~mL})$, were added $\mathrm{K}_{2} \mathrm{CO}_{3}(31.0 \mathrm{~g}, 222.7 \mathrm{mmol})$ and 2-iodopropane $(17 \mathrm{~mL}, 170.3 \mathrm{mmol})$. The reaction mixture was refluxed during $64 \mathrm{~h}$ and then cooled to room temperature. Evaporation of acetone afforded a residue which was taken up in $200 \mathrm{~mL}$ of a $1 / 1$ mixture of water and ether. Aqueous phase was extracted three times with ether, and the combined organic phases were washed with saturated $\mathrm{Na}_{2} \mathrm{CO}_{3}, \mathrm{H}_{2} \mathrm{O}$, brine, dried over $\mathrm{Na}_{2} \mathrm{SO}_{4}$, and concentrated to give 4 as a pale brown oil (10.8 g, 99\%) which was used without any purification. IR 2977, 1644, 1604, 1368, 1238, $1099 \mathrm{~cm}^{-1}$; ${ }^{1} \mathrm{H}$ NMR $\left(300 \mathrm{MHz}, \mathrm{CDCl}_{3}\right) \delta 1.28(\mathrm{~d}, J=6.2 \mathrm{~Hz}, 6 \mathrm{H})$, 1.98 (quint., $J=6.4 \mathrm{~Hz}, 2 \mathrm{H}$ ), 2.35 (t, $J=6.4 \mathrm{~Hz}, 2 \mathrm{H}$ ), 2.54 (t, $J=6.1 \mathrm{~Hz}, 2 \mathrm{H}$ ), 3.02 (d, $J=6.4$ Hz, $2 \mathrm{H}$ ), 4.54 (hept., $J=6.2 \mathrm{~Hz}, 1 \mathrm{H}$ ), 4.88 (dd, $J=10.1 \mathrm{~Hz}, 1.8 \mathrm{~Hz}, 1 \mathrm{H}$ ), 4.98 (dd, $J=16.8 \mathrm{~Hz}$, $1.8 \mathrm{~Hz}, 1 \mathrm{H}), 5.77$ (ddt, $J=16.8 \mathrm{~Hz}, 10.1 \mathrm{~Hz}, 6.4 \mathrm{~Hz}, 1 \mathrm{H}),{ }^{13} \mathrm{C} \mathrm{NMR}\left(75 \mathrm{MHz}, \mathrm{CDCl}_{3}\right) \delta 21.2$, 23.0 (2 C), 25.7, 26.6, 36.6, 70.3, 113.9, 118.7, 136.7, 171.1, 197.9; MS (ESI) 217.1 $\mathrm{C}_{12} \mathrm{H}_{18} \mathrm{NaO}_{2}$ $(\mathrm{M}+\mathrm{Na})^{+}$.

2,6-Diallyl-3-isopropoxycyclohex-2-enone 5 . To a cooled $\left(-78^{\circ} \mathrm{C}\right)$ solution of diisopropylamine (8.6 mL, $61.3 \mathrm{mmol})$ in THF (72 mL), was added BuLi (1.6 M in hexanes, $35.9 \mathrm{~mL}, 57.4 \mathrm{mmol}$ ) and stirring was continued during $30 \mathrm{~min}$. At the same temperature was added dropwise a solution of $4(10.8 \mathrm{~g}, 55.6 \mathrm{mmol})$ in THF $(70 \mathrm{~mL})$ and stirring was continued during $1 \mathrm{~h}$. Then, $97 \%$ allyl bromide $(6.0 \mathrm{~mL}, 67.2 \mathrm{mmol}$ ) was added dropwise and the reaction mixture was slowly warmed to room temperature overnight. Saturated $\mathrm{NH}_{4} \mathrm{Cl}$ and $\mathrm{Et}_{2} \mathrm{O}$ were added and the aqueous phase was extracted with $\mathrm{Et}_{2} \mathrm{O}$. The combined organic phases were dried over $\mathrm{Na}_{2} \mathrm{SO}_{4}$, and evaporated to give 5 as a crude oil (13.05 g) which was used directly in the next step without any further purification. An analytical sample of $\mathbf{5}$ could be obtained by column chromatography on silica gel (heptane/ethyl acetate: 95/5). IR 2977, 1639, 1610, 1453, 1370, 1237, 1106, 991, $910 \mathrm{~cm}^{-1} ;{ }^{1} \mathrm{H}$ NMR (300 MHz, $\left.\mathrm{CDCl}_{3}\right) \delta 1.27(\mathrm{~d}, J=6.2 \mathrm{~Hz}, 3 \mathrm{H}), 1.29(\mathrm{~d}, J=6.2 \mathrm{~Hz}, 3 \mathrm{H})$, 1.69 (m, 1 H), 2.09 (m, 2 H), 2.23 (m, 1 H), 2.50-2.62 (m, 3 H), 3.02 (d, $J=6.4$ Hz, 2 H), 4.54 (hept., $J=6.2 \mathrm{~Hz}, 1 \mathrm{H}$ ), 4.87 (dd., $J=10.1 \mathrm{~Hz}, 1.8 \mathrm{~Hz}, 1 \mathrm{H}$ ), 4.98 (dd, $J=17.1 \mathrm{~Hz}, 1.8 \mathrm{~Hz}, 1 \mathrm{H}$ ), 5.03 (2 dd overlap, $J=17.1 \mathrm{~Hz}, 10.1 \mathrm{~Hz}, 1.5 \mathrm{~Hz}, 2 \mathrm{H}$ ), 5.77 (m, $2 \mathrm{H}) ;{ }^{13} \mathrm{C}$ NMR $(75 \mathrm{MHz}$, $\left.\mathrm{CDCl}_{3}\right) \delta 23.0$ (2 C), 24.7, 25.7, 26.9, 34.3, 44.3, 70.1, 113.8, 116.5, 118.1, 136.7 (2 C), 170.3, 198.8; HRMS (ESI) $\mathrm{m} / \mathrm{z}$ found 257.1511, calcd for $\mathrm{C}_{15} \mathrm{H}_{22} \mathrm{NaO}_{2}(\mathrm{M}+\mathrm{Na})^{+} 257.1517$

2,4-Diallyl-3-methylcyclohex-2-enone 6. To a cooled $\left(0{ }^{\circ} \mathrm{C}\right)$ solution of crude 5 (13.05 g, $55.7 \mathrm{mmol})$ in THF $(70 \mathrm{~mL})$, were added dropwise a solution of MeLi (1.6 $\mathrm{M}$ in Et $2 \mathrm{O}, 52.0 \mathrm{~mL}$, $83.2 \mathrm{mmol}$ ). After addition was completed, stirring was continued for $30 \mathrm{~min}$ at room temperature. Then $1 \mathrm{~N} \mathrm{HCl}(139 \mathrm{~mL})$ was carrefully added at $0^{\circ} \mathrm{C}$ and vigorous stirring was maintained during $30 \mathrm{~min}$. The organic phase was separated and aqueous phase was extracted three times with $\mathrm{Et}_{2} \mathrm{O}$. The combined organic phases were dried over $\mathrm{Na}_{2} \mathrm{SO}_{4}$, filtrated and evaporated. Column chromatography on silica gel (heptane/ethyl acetate: 98/2) afforded 6 as a colorless oil (9.2 g, 87\% over two steps). IR 2925, 1660, 1638, 1443, 1377, 994, $908 \mathrm{~cm}^{-1} ;{ }^{1} \mathrm{H}$ NMR (300 MHz, $\left.\mathrm{CDCl}_{3}\right) \delta 1.91(\mathrm{~m}, 1 \mathrm{H}), 1.94(\mathrm{~s}, 3 \mathrm{H}), 2.02(\mathrm{~m}, 1 \mathrm{H}), 2.21(\mathrm{~m}, 1 \mathrm{H}), 2.26(\mathrm{~m}, 1$ H), 2.34 (m, 1 H), 2.43 (m, 1 H), 2.49 (m, 1 H), 3.04 (d, J = 5.9 Hz, 2 H), 4.92 (m, 2 H), 5.06 (m, $2 \mathrm{H}), 5.70(\mathrm{~m}, 1 \mathrm{H}), 5.77(\mathrm{~m}, 1 \mathrm{H}) ;{ }^{13} \mathrm{C}$ NMR $\left(75 \mathrm{MHz}, \mathrm{CDCl}_{3}\right) \delta 19.9,25.3,29.3,33.4,35.6$, 
40.8, 114.2, 117.0, 133.2, 134.5, 136.4, 159.4, 197.7; HRMS (ESI) m/z found 213.1256, calcd for $\mathrm{C}_{17} \mathrm{H}_{26} \mathrm{NaO}(\mathrm{M}+\mathrm{Na})^{+} 213.1255$.

2,4-Diallyl-3,3-dimethylcyclohexanone 7. To a suspension of $\mathrm{CuI}$ (18.2 g, $95.6 \mathrm{mmol})$ in $\mathrm{Et}_{2} \mathrm{O}$ $(270 \mathrm{~mL})$ at $0{ }^{\circ} \mathrm{C}$, was added dropwise $\mathrm{MeLi}\left(1.6 \mathrm{M}\right.$ in $\left.\mathrm{Et}_{2} \mathrm{O}, 56.8 \mathrm{~mL}, 90.9 \mathrm{mmol}\right)$. Upon cooling at $-78{ }^{\circ} \mathrm{C}$, freshly distilled $\mathrm{Et}_{2} \mathrm{O} \cdot \mathrm{BF}_{3}(11.3 \mathrm{~mL}, 89.2 \mathrm{mmol})$ was added dropwise and, after $10 \mathrm{~min}$ at this temperature, a solution of $\mathbf{6}(1.7 \mathrm{~g}, 8.93 \mathrm{mmol})$ in THF $(7.0 \mathrm{~mL})$ was added. The reaction was stirred for $3 \mathrm{~h} 30$ at $-78{ }^{\circ} \mathrm{C}$ and quenched by addition of $380 \mathrm{~mL}$ of a 9/1 solution of saturated $\mathrm{NH}_{4} \mathrm{Cl}$ and $25 \%$ aqueous ammonia. The temperature was allowed to increase and stirring was continued under normal atmosphere until the mixture turned deep blue. The suspension was filtered through celite, the organic layer separated, and the aqueous layer extracted with $\mathrm{Et}_{2} \mathrm{O}$. The combined organic phases were dried over $\mathrm{Na}_{2} \mathrm{SO}_{4}$, and briefly purified on silica gel to give a colorless oil as a mixture of two epimers (4/3) (1.55 g, 83\%). IR 2970, 2935, 2869, 1711, 1639, 1432, 1371, 997, $908 \mathrm{~cm}^{-1}$; HRMS (ESI) m/z found 229.1569 calcd for $\mathrm{C}_{14} \mathrm{H}_{22} \mathrm{NaO}(\mathrm{M}+\mathrm{Na})^{+}$229.1568. Analytical samples of $7 \boldsymbol{c}$ and $7 \boldsymbol{t}$ were obtained by column chromatography on silica gel (heptane/ethyl acetate: 99/1).

(2S*,4R*)2,4-Diallyl-3,3-dimethylcyclohexanone 7c. ${ }^{1} \mathrm{H}$ NMR (300 MHz, $\left.\mathrm{CDCl}_{3}\right) \delta 0.58$ (s, 3 H), 1.10 (s, 3 H), 1.40 (m, 1 H), 1.61 (m, 1 H), 1.66 (m, 1 H), 1.99 (m, 1 H), 2.07 (m, 1 H), 2.24 (dd, $J=9.8 \mathrm{~Hz}, 2.3 \mathrm{~Hz}, 1 \mathrm{H}$ ), 2.29 (m, $1 \mathrm{H}), 2.32$ (m, $1 \mathrm{H}), 2.39$ (m, $1 \mathrm{H}), 2.53$ (m, $1 \mathrm{H}), 4.91$ (m, $2 \mathrm{H}), 5.00$ (m, $2 \mathrm{H}), 5.71(\mathrm{~m}, 1 \mathrm{H}), 5.78(\mathrm{~m}, 1 \mathrm{H}) ;{ }^{13} \mathrm{C}$ NMR (75 MHz, $\left.\mathrm{CDCl}_{3}\right) \delta$ 15.3, 26.7, 27.4, 28.8, 34.7, 42.1, 43.2, 46.9, 61.0, 114.9, 116.0, 137.8, 138.4, 211.5.

$\left(2 \boldsymbol{R}^{*}, \mathbf{4} \boldsymbol{R}^{*}\right)$ 2,4-Diallyl-3,3-dimethylcyclohexanone $\mathbf{7 t} .{ }^{1} \mathrm{H} \mathrm{NMR}\left(300 \mathrm{MHz}, \mathrm{CDCl}_{3}\right) \delta 0.88$ (s, 3 H), 0.96 (s, 3 H), 1.53 (m, 1 H), 1.69 (m, 1 H), 1.84 (m, 1 H), 1.97 (m, 1 H), 2.13 (dd, J = 11.1 Hz, $4.1 \mathrm{~Hz}, 1 \mathrm{H}), 2.23$ (m, $1 \mathrm{H}), 2.25$ (m, $1 \mathrm{H}), 2.28$ (m, $1 \mathrm{H}), 2.33$ (m, $1 \mathrm{H})$ ), 2.39 (m, $1 \mathrm{H})$, 4.96 (m, $2 \mathrm{H}), 5.03$ (m, $2 \mathrm{H}), 5.64(\mathrm{~m}, 1 \mathrm{H}), 5.78(\mathrm{~m}, 1 \mathrm{H}) ;{ }^{13} \mathrm{C} \mathrm{NMR}\left(75 \mathrm{MHz}, \mathrm{CDCl}_{3}\right) \delta 23.5$, 25.8, 26.8, 30.8, 33.5, 37.8, 40.2, 41.1; 61.2, 115.9, 116.1, 136.2, 137.8, 213.8.

2,4,6-Triallyl-3,3-dimethylcyclohexanone 8. To a cooled $\left(0^{\circ} \mathrm{C}\right)$ solution of diisopropylamine (4.2 mL, $29.9 \mathrm{mmol})$ in THF $(10.7 \mathrm{~mL})$, was added BuLi $(2.0 \mathrm{M}$ in hexanes, $13.8 \mathrm{~mL}$, $27.6 \mathrm{mmol}$ ) and stirring was continued during $30 \mathrm{~min}$ at the same temperature. The solution was cooled at $-78{ }^{\circ} \mathrm{C}$ and a solution of the mixture of $7 \boldsymbol{c}+7 \boldsymbol{t}(4.75 \mathrm{~g}, 23.0 \mathrm{mmol})$ in THF $(4.6 \mathrm{~mL})$ was added dropwise. Stirring was continued during $1 \mathrm{~h}$ at the same temperature. Then, a solution of $97 \%$ allyl bromide $(2.7 \mathrm{~mL}, 30.3 \mathrm{mmol})$ in HMPA (15.0. mL, $86.2 \mathrm{mmol}$ ) was added dropwise and the mixture was slowly warmed to room temperature overnight. Saturated $\mathrm{NH}_{4} \mathrm{Cl}$ and $\mathrm{Et}_{2} \mathrm{O}$ were added and the aqueous phase was extracted twice with $\mathrm{Et}_{2} \mathrm{O}$. The combined organic phases were dried over $\mathrm{Na}_{2} \mathrm{SO}_{4}$, filtrated and evaporated. Column chromatography on silica gel (heptane/ethyl acetate: 99/1) gave 8 as a 2/3 $\beta / \alpha$ mixture (4.4 g, 78\%). IR 2971, 1707, 1639, 1435, 1390, 1370, 994, $908 \mathrm{~cm}^{-1}$; HRMS (ESI) $\mathrm{m} / \mathrm{z}$ found 269.1881, calcd for $\mathrm{C}_{17} \mathrm{H}_{26} \mathrm{NaO}$ $(\mathrm{M}+\mathrm{Na})^{+} 269.1881$. Analytical samples of $\mathbf{8} \beta$ and $\mathbf{8} \alpha$ were obtained by column chromatography on silica gel (heptane/ethyl acetate: 100/0.9).

(2S*,4S*,6S*)-2,4,6-triallyl-3,3-dimethylcyclohexanone 8$\beta$. ${ }^{1} \mathrm{H}$ NMR (300 $\left.\mathrm{MHz}, \mathrm{CDCl}_{3}\right)$ $\delta 0.63$ (s, $3 \mathrm{H}), 1.13$ (s, $3 \mathrm{H}), 1.56$ (m, $1 \mathrm{H}), 1.69$ (m, $1 \mathrm{H}), 1.82$ (m, $1 \mathrm{H}), 1.93$ (m, $1 \mathrm{H}), 2.02$ 
(m, $1 \mathrm{H}), 2.28$ (m, $1 \mathrm{H}), 2.42$ (m, $2 \mathrm{H}), 2.45$ (m, $2 \mathrm{H}), 2.55$ (m, $1 \mathrm{H}), 4.92$ (m, $2 \mathrm{H}), 4.99$ (m, 2 $\mathrm{H}), 5.03(\mathrm{~m}, 2 \mathrm{H}), 5.61(\mathrm{~m}, 1 \mathrm{H}), 5.73(\mathrm{~m}, 1 \mathrm{H}), 5.78(\mathrm{~m}, 1 \mathrm{H}) ;{ }^{13} \mathrm{C}$ NMR $\left(75 \mathrm{MHz}, \mathrm{CDCl}_{3}\right)$ $\delta 15.5,26.9,27.4,32.4,34.6,36.1,41.8,43.4,49.6,57.3,115.0,116.1,117.0,135.0,137.8$, 138.4, 214.2.

$\left(2 R^{*}, 4 S^{*}, 6 S^{*}\right)-2,4,6$-triallyl-3,3-dimethylcyclohexanone $8 \alpha .{ }^{1} \mathrm{H}$ NMR (300 $\left.\mathrm{MHz}, \mathrm{CDCl}_{3}\right)$ $\delta 0.81$ (s, 3 H), 1.08 (s, 3 H), 1.45 (m, 1 H), 1.55 (m, 1 H), 1.90 (m, 2 H), 2.00 (m, 1 H), 2.27 (m, 2 H), 2.38 (m, 1 H), 2.42 (m, 1 H), 2.50 (m, 1 H), 2.52 (m, 1 H), 4.96 (m, 2 H), 5.00 (m, 2 $\mathrm{H}), 5.07(\mathrm{~m}, 2 \mathrm{H}), 5.70(\mathrm{~m}, 1 \mathrm{H}), 5.77(\mathrm{~m}, 1 \mathrm{H}), 5.80(\mathrm{~m}, 1 \mathrm{H}) ;{ }^{13} \mathrm{C}$ NMR $\left(75 \mathrm{MHz}, \mathrm{CDCl}_{3}\right)$ $\delta$ 24.2, 26.8, 27.5, 31.4, 32.5, 33.4, 42.9, 44.8, 44.9, 56.2, 115.1, 116.1, 116.2, 136.4, 137.8, 138.4, 212.1.

2,4,6-Triallyl-3,3-dimethylcyclohexanone trimethylsilyl enol ethers 9. To a cooled $\left(0{ }^{\circ} \mathrm{C}\right)$ solution of a mixture of cyclohexanones $8(1 \mathrm{~g}, 4.06 \mathrm{mmol})$ in $\mathrm{CH}_{2} \mathrm{Cl}_{2}(7.0 \mathrm{~mL})$ was added freshly distilled $\mathrm{Et}_{3} \mathrm{~N}$ (1.13 mL, $\left.8.12 \mathrm{mmol}\right)$. The reaction mixture was stirred during $15 \mathrm{~min}$ and TMSOTf (1.1 mL, $6.08 \mathrm{mmol})$ was added dropwise. The solution was slowly warmed to room temperature and stirred overnight. Pentane was added and the two layers were separated. The pentane phase was washed with satured $\mathrm{NH}_{4} \mathrm{Cl}$ and with brine. The organic phase was dried over $\mathrm{Na}_{2} \mathrm{SO}_{4}$, and concentrated to a colorless oil which was used without further purification in the next step. 9 was obtained quantitatively as a mixture of 3 isomers. The proportion of each isomer could not be determined by NMR spectroscopy.

Methyl 3-oxo-3-((1R*,3S*,5S*)-1,3,5-triallyl-4,4-dimethyl-2-oxocyclohexyl)propanoate 11. To a cooled $\left(-10{ }^{\circ} \mathrm{C}\right)$ solution of silyl enol ethers 9 (570 mg, $\left.1.79 \mathrm{mmol}\right)$ in $\mathrm{CH}_{2} \mathrm{Cl}_{2}(9 \mathrm{~mL})$ were successively added dropwise redistillated $\mathrm{Et}_{2} \mathrm{O} \cdot \mathrm{BF}_{3}(68 \mu \mathrm{L}, 0.54 \mathrm{mmol})$ and freshly distilled malonyl dichloride $184 \mu \mathrm{L}, 1.88 \mathrm{mmol}$ ). The reaction mixture was stirred during $2 \mathrm{~h}$, warmed to room temperature during $2 \mathrm{~h}$, quenched by DMAP (773 $\mathrm{mg}, 6.27 \mathrm{mmol}$ ) and stirred during $15 \mathrm{~min}$. The solution was diluted by $\mathrm{Et}_{2} \mathrm{O}$ and hydrolysed by $1 \mathrm{~N} \mathrm{HCl}$. The layers were separated and the aqueous phase was extracted 3 times by $\mathrm{Et}_{2} \mathrm{O}$. The combined organic phases were washed with brine, dried over $\mathrm{Na}_{2} \mathrm{SO}_{4}$, and concentrated to a yellow oil. Purification by flash chromatography $\left(\mathrm{CH}_{2} \mathrm{Cl}_{2} / \mathrm{MeOH}\right.$ : 95/5) gave 10 (160 mg, 27\%) as a yellow oil and a 1/1 mixture of ketones (356 mg, 60\%) as a colorless oil. To a solution of ketoacid 10 (100 mg, $0.30 \mathrm{mmol}$ ) in acetone $(0.2 \mathrm{~mL})$ at room temperature under an argon atmosphere, was added dropwise TMSdiazomethane ( $2 \mathrm{M}$ in hexanes, $250 \mu \mathrm{L}, 0.5 \mathrm{mmol}$ ) and the reaction mixture was stirred for 4 h. It was directly evaporated and purified by flash chromatography (heptane/ethyl acetate: 95/5) to afford $91 \mathrm{mg}$ (87\%) of keto ester 11 as a colorless oil. IR 2973, 1753, 1699, 1440, 1436, 995, $913 \mathrm{~cm}^{-1}$; ${ }^{1} \mathrm{H}$ NMR (300 MHz, $\left.\mathrm{CDCl}_{3}\right) \delta 0.57$ (s, $\left.3 \mathrm{H}\right), 1.08$ (s, $\left.3 \mathrm{H}\right), 1.13(\mathrm{~m}, 1 \mathrm{H}), 1.64$ (m, $1 \mathrm{H}), 1.83$ (m, $1 \mathrm{H}), 2.06$ (m, $1 \mathrm{H}), 2.21$ (dd, $J=10.1 \mathrm{~Hz}, 2.4 \mathrm{~Hz}, 1 \mathrm{H}), 2.34$ (m, $1 \mathrm{H}), 2.35$ (m, 1 H), $2.39(\mathrm{~m}, 1 \mathrm{H}), 2.57(\mathrm{~m}, 1 \mathrm{H}), 2.60(\mathrm{~m}, 1 \mathrm{H}), 3.17$ (d, $J=16.3 \mathrm{~Hz}, 1 \mathrm{H}), 3.38(\mathrm{~d}, J=$ $16.3 \mathrm{~Hz}, 1 \mathrm{H}), 3.71$ (s, $3 \mathrm{H}), 4.97$ (m, $2 \mathrm{H}), 5.05$ (m, $2 \mathrm{H}), 5.09$ (m, $2 \mathrm{H}), 5.57$ (m, $1 \mathrm{H}), 5.72$ (m, $1 \mathrm{H}), 5.82$ (m, $1 \mathrm{H}) ;{ }^{13} \mathrm{C}$ NMR $\left(75 \mathrm{MHz}, \mathrm{CDCl}_{3}\right) \delta$ 15.4, 26.4, 27.5, 34.6, 35.6, 38.4, 42.9, 45.3, 52.4, 59.3, 61.9, 67.6, 116.3, 116.4, 119.3, 131.8, 137.0, 137.3, 167.0, 199.8, 207.8; HRMS (ESI) $\mathrm{m} / \mathrm{z}$ found 369.2042, calcd for $\mathrm{C}_{21} \mathrm{H}_{30} \mathrm{NaO}_{4}(\mathrm{M}+\mathrm{Na})^{+} 369.2042$. 
$\left(1 R^{*}, 3 R^{*}, 8 S^{*}, 10 R^{*}\right)-8,10$-Diallyl-3,11,11-trimethyl-4-oxa-tricyclo[6.3.1.0 $\left.{ }^{1,5}\right]$ dode-5-ene-7,12dione 12. To a cooled $\left(-10^{\circ} \mathrm{C}\right)$ solution of silyl enol ethers 9 (503 mg, $\left.1.58 \mathrm{mmol}\right)$ in $\mathrm{CH}_{2} \mathrm{Cl}_{2}$ $(8 \mathrm{~mL})$ were successively added dropwise redistillated $\mathrm{Et}_{2} \mathrm{O} \cdot \mathrm{BF}_{3}(59 \mu \mathrm{L}, 0.47 \mathrm{mmol})$ and freshly distilled malonyl dichloride (310 $\mu \mathrm{L}, 3.18 \mathrm{mmol})$. The reaction mixture was stirred during $2 \mathrm{~h}$, warmed to room temperature during $18 \mathrm{~h}$, quenched by DMAP (543 mg, $4.40 \mathrm{mmol}$ ) and stirred during $15 \mathrm{~min}$. The solution was diluted by $\mathrm{Et}_{2} \mathrm{O}$ and hydrolysed by $1 \mathrm{~N} \mathrm{HCl}$. The layers were separated and the aqueous phase was extracted 3 times by $\mathrm{Et}_{2} \mathrm{O}$. The combined organic phases were washed with brine, dried over $\mathrm{Na}_{2} \mathrm{SO}_{4}$, and concentrated to a yellow oil. Purification by flash chromatography $\left(\mathrm{CH}_{2} \mathrm{Cl}_{2} / \mathrm{MeOH}\right.$ : 96/4) gave 12 (90 mg, 17\%) as a yellow oil, 10 (120 mg, 24\%) as a colorless oil and a 5/6 mixture of ketones (250 mg, 48\%) as a colorless oil. 12: IR 2976, 1727, 1626, 1377, 1193, 995, $912 \mathrm{~cm}^{-1}$; ${ }^{1} \mathrm{H}$ NMR (300 MHz, $\left.\mathrm{CDCl}_{3}\right) \delta 0.73$ (s, $3 \mathrm{H}$ ), 0.99 (s, 3 H), 1.39 (m, 1 H), 1.52 (d, $J=6.4$ Hz, 3 H), 1.65 (m, 1 H), 1.71 (dd, $J=14.0 \mathrm{~Hz}, 6.9$ Hz, 1 H), 1.89 (m, $1 \mathrm{H}$ ), 2.00 (dd, $J=13.3 \mathrm{~Hz}, 4.2 \mathrm{~Hz}, 1 \mathrm{H}$ ), 2.29 (m, $1 \mathrm{H}$ ), 2.50 (dd overlap, $J=7.8$ Hz, 6.9 Hz, 2 H), 3.06 (dd, $J=14.0 \mathrm{~Hz}, 9.7 \mathrm{~Hz}, 1 \mathrm{H}$ ), 4.50 (m, $1 \mathrm{H}), 5.00$ (m, 2 H), 5.05 (m, 2 $\mathrm{H}), 5.62(\mathrm{~m}, 1 \mathrm{H}), 5.66(\mathrm{~m}, 1 \mathrm{H}), 5.86(\mathrm{~s}, 1 \mathrm{H}) ;{ }^{13} \mathrm{C} \mathrm{NMR}\left(75 \mathrm{MHz}, \mathrm{CDCl}_{3}\right) \delta$ 16.0, 20.2, 23.7, 30.0, 35.3 (2 C), 39.7, 40.3, 45.3, 62.0, 69.3, 81.6, 107.1, 117.0, 118.0, 134.0, 136.5, 177.6, 197.3, 205.5; HRMS (ESI) $\mathrm{m} / \mathrm{z}$ found 337.1777, calcd for $\mathrm{C}_{20} \mathrm{H}_{26} \mathrm{NaO}_{3}(\mathrm{M}+\mathrm{Na})^{+}$337.1780.

\section{Acknowledgements}

We thank the Alban fellowship (European Community) for supporting the PhD work and the Institut de Chimie des Substances Naturelles (CNRS) for a grant to B. T.

\section{References and Notes}

1. For recent reviews, see: (a) Ciochina, R.; Grossman, R. B. Chem. Rev. 2006, 106, 3963. (b) Cuesta-Rubio, O.; Piccinelli, A. L.; Rastrelli, L. In Studies in Natural Product Chemistry (Bioactive Naturals Products, Part L) (Ed: Atta-ur Rahman), Elsevier: Amsterdam, 2005, Vol. 32, pp 671-720. (c) Baggett, S.; Mazzola, E. P.; Kennelly, E. J. In Studies in Natural Product Chemistry (Bioactive Naturals Products, Part L) Atta-ur Rahman, Ed., Elsevier: Amsterdam, 2005, Vol. 32, pp 721-771.

2. Cuesta-Rubio, O.; Velez-Castro, H.; Frontana-Uribe, B. A.; Cardenas, J. Phytochemistry 2001, 57, 279.

3. (a) McCandlish, L. E.; Hanson, J. C.; Stout, G. H. Acta Crystallogr., Sect. B 1976, 321793.

(b) Piccinelli, A. L.; Cuesta-Rubio, O.; Barrios Chica, M.; Mahmood, N.; Pagano, B.; Pavone, M.; Barone, V.; Rastrelli, L. Tetrahedron 2005, 61, 8206.

4. Cuesta-Rubio, O.; Padron, A.; Velez Castro, H.; Pizza, C.; Rastrelli, L. J. Nat. Prod. 2001, 64, 973. 
5. (a) previous structure: de Oliveira, C. M. A.; Porto, A. L. M.; Bittrich, V.; Marsaioli, A. J. Phytochemistry 1999, 50, 1073. (b) revised structure: Bittrich, V.; Amaral, M. C. E.; Machado, S. M. F.; Marsaioli, A. J. Z. Naturforsch. 2003, 58c, 643. (c) this compound, or its enantiomer, is also known as plukenetione D/E: Henry, G. E.; Jacobs, H.; Carrington, C. M. S.; McLean, S.; Reynolds, W. F. Tetrahedron 1999, 55, 1581.

6. Roux, D.; Hadi, H. A.; Thoret, S.; Guénard, D.; Thoison, O.; Païs, M.; Sévenet, T. J. Nat. Prod. 2000, 63, 1070.

7. Fukuyama, Y.; Kuwayama, A.; Minami, H. Chem. Pharm. Bull. 1997, 45, 947.

8. (a) Matsuhisa, M.; Shikishima, Y.; Takaishi, Y.; Honda, G.; Ito, M.; Takeda, Y.; Shibata, H.; Higuti, T.; Kodzhimatov, O. K.; Ashurmetov, O. J. Nat. Prod. 2001, 64, 973. (b) structure corrected by Grossman for the axial position of the C-10 prenyl (see ref 1a).

9. (a) Kuramochi, A.; Usuda, H.; Yamatsugu, K.; Kanai, M.; Shibasaki, M. J. Am. Chem. Soc. 2005, 127, 14200. (b) Siegel, D. R.; Danishefsky, S. J. J. Am. Chem. Soc. 2006, 128, 1048.

10. (a) Rodeschini, V.; Ahmad, N. M.; Simpkins, N. S. Org. Lett. 2006, 8, 5283. (b) Rodeschini, V.; Simpkins, N. S.; Wilson, C. J. Org. Chem. 2007, 72, 4265. (c) Ahmad, N. M.; Rodeschini, V.; Simpkins, N. S.; Ward, S. E.; Blake, A. J. J. Org. Chem. 2007, 72, 4803. (d) Qi, J.; Porco, Jr., J. A. J. Am. Chem. Soc. 2007, 129, 12682. (e) Tsukano, C.; Siegel, D. R.; Danishefsky, S. J. Angew. Chem. Int. Ed. 2007, 46, 8840.

11. Nuhant, P.; David, M.; Pouplin, T.; Delpech, B.; Marazano, C. Org. Lett. 2007, 9, 287.

12. Hamed, W.; Brajeul, S.; Mahuteau-Betzer, F.; Thoison, O.; Mons, S.; Delpech, B.; Hung, N. V.; Sévenet, T.; Marazano, C. J. Nat. Prod. 2006, 69, 774.

13. (a) Pouplin, T.; Tolon, B.; Nuhant, P.; Delpech, B.; Marazano, C. Eur. J. Org. Chem. 2007, 5117. (b) Raikar, S. B.; Nuhant, P.; Delpech, B.; Marazano, C. Eur. J. Org. Chem. 2008, 1358.

14. Schönwälder, K.-H.; Kollatt, P.; Stezowski, J. J.; Effenberger, F. Chem. Ber. 1984, 117, 3280.

15. (a) Stetter, H.; Dierichs, W. Chem. Ber. 1952, 85, 1061. (b) Verhé, R.; Schamp, N.; De Buyck, L.; De Kimpe, N.; Sadones, M. Bull. Soc. Chim. Belg. 1975, 84, 747. (c) Renouf, P.; Poirier, J.-M.; Duhamel, P. J. Chem. Soc., Perkin Trans. 1 1997, 1739.

16. Cargill, R. L.; Bushey, D. F.; Dalton, J. R.; Prasad, R. S.; Dyer, R. D.; Bordner, J. J. Org. Chem. 1981, 46, 3389.

17. Stork, G.; Danheiser, R. L. J. Org. Chem. 1973, 38, 1775.

18. (a) Karpf, M.; Dreiding, A. Helv. Chim. Acta 1981, 64, 1123. (b) for a review, see: Yamamoto, Y. Angew. Chem. Int. Ed. 1986, 25, 947.

19. Spessard, S. J.; Stoltz, B. M. Org. Lett. 2002, 4, 1943.

20. Dalling, D. K.; Grant, D. M. J. Am. Chem. Soc. 1967, 89, 6612. ibid 1972, 94, 5318.

21. Xiao, Z. Y.; Mu, Q.; Shiu, W. K. P.; Zeng, Y. H.; Gibbons, S. J. Nat. Prod. 2007, 70, 1779.

22. Sang, S.; Liao, C.-H.; Pan, M.-H.; Rosen, R. T.; Lin-Shiau, S.-Y.; Lin, J.-K.; Ho, C.-T. Tetrahedron 2002, 58, 10095.

23. Mehta, G.; Bera, M. K. Tetrahedron, Lett. 2004, 45, 1113. 
24. Eliel, E. L.; Wilen, S. H.; Mander, L. N. Stereochemistry of Organic Compounds, John Wiley \& Sons: New York, 1994.

25. Verotta, L.; Appendino, G.; Belloro, E.; Bianchi, F.; Sterner, O.; Lovati, M.; Bombardelli, E. J. Nat. Prod. 2002, 65, 433. 